\title{
Primary small B cell non-Hodgkin Lymphoma of the Lacrimal Sac Upon Chronic Dacryocystitis
}

\author{
Murat Gumussoy $^{1 *}$ Sinan Uluyol ${ }^{1}$, Ulku Kucuk ${ }^{2}$, Gokhan Kurtoglu ${ }^{1}$, Tolga Kandogan ${ }^{1}$, \\ Ibrahim Cukurova ${ }^{1}$
}

\begin{abstract}
Objective: Primary non-Hodgkin lymphoma of the lacrimal sac is an extremely rare tumor. In this article, we report a 44-year-old female who was referred for dacryocystorhinostomy with complaints of epiphora and swelling on the right lacrimal sac region. She had slight epiphora for 8 years, which increased within 6 months, with concomitant swelling between the eye and the nose. A hard and fixed mass was detected on palpation just below the medial canthus. Magnetic resonance imaging showed a 30x35 mm tumoral, lesion which invaded the medial wall of the right orbit and compressed the medial rectus muscle. Histopathologic examination of the tumor revealed a small B cell non-Hodgkin lymphoma. As a conclusion, we suggest that if symptoms of a chronic dacryocystitis patient deteriorates, malignancy should be suspected
\end{abstract}

\section{Introduction}

Malignant tumors of the lacrimal sac are unusual and most of them are epithelial tumors. Primary nonHodgkin lymphomas (NHL) of this area are extremely rare[1-3]. These patients have symptoms like epiphora and swelling in periorbital region. Early suspicion and immediate biopsy are prerequisites for the diagnosis of malignancies in this area.

We present a patient with primary B cell NHL of the lacrimal sac developed secondary to chronic dacryocystitis and reviewed literature.To our knowledge it is the first case that primary lymphoma of the lacrimal sac was developed secondary to chronic dacryocystitis

\section{Material and Methods}

Forty-four years old female patient with complaints of epiphora on the right eye for eight years and a growing mass in the right periorbital region for six months referred to our clinic with preliminary diagnosis of chronic dacryocystitis.

Physical examination revealed a firm, non-tender and irregular mass extending from medial canthus through nasolabial sulcus and lateral nasal cavity (Picture 1).

Endoscopic nasal examination revealed hyperemic mucosa with edema at the level of lacrimal sac.
In the ophthalmologic examination, there was no drainage through right nasolacrimal system by irrigation, and eye movements were within normal limits.

Anterior segment, optical disc, macula and visual examination were found within normal limits in both eyes.

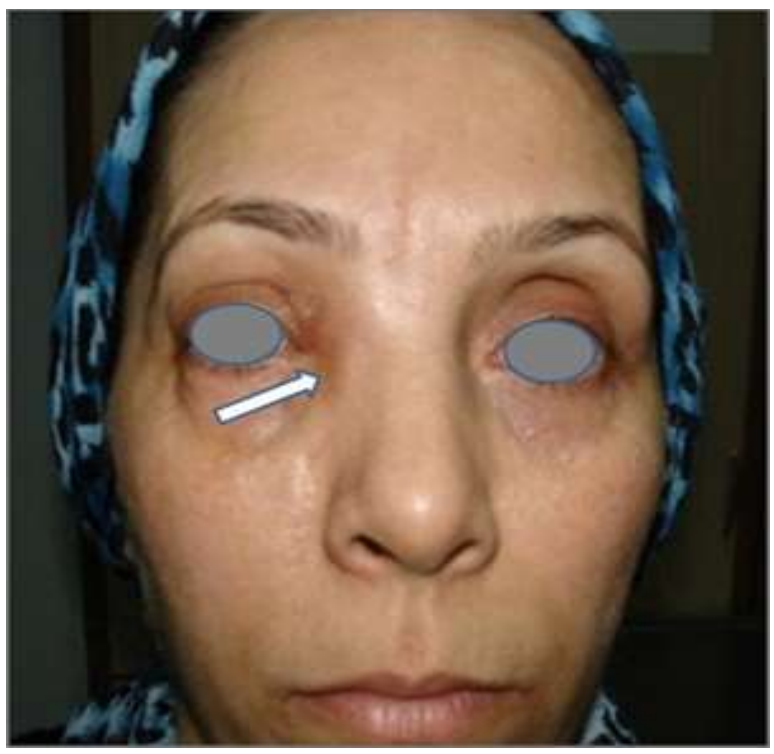

Picture 1: Physical examination (right eye and solid mass involving the lacrimal sac region

Received 24-05-2016 Accepted 23-06-2016 Available Online 15-07-2016

1 Tepecik Educational and Training Hospital Yenisehir, Izmir

2 Tepecik Education and Research Hospital, Department of Pathology, Izmir, Turkey

* Corresponding Author :Murat Gumussoy: E-mail: mgumussoy@hotmail.comPhone: +90 2324443560 
Magnetic resonance imaging scans showed a mass of $30 \times 35 \mathrm{~mm}$ in size, invading the nasal side of the right orbita, including the right nasolacrimal duct and continuing to the level of inferior nasal concha. Compression of the medial rectus muscle was observed. Other structures were normal in right orbita (Picture 2).
Multiple incisional biopsies were made from the mass and sent to pathology department. Histopathological examination of the specimens revealed a mixture of small to medium sized, mildly atypical uniform lymphocytes (Figure 3A, B).

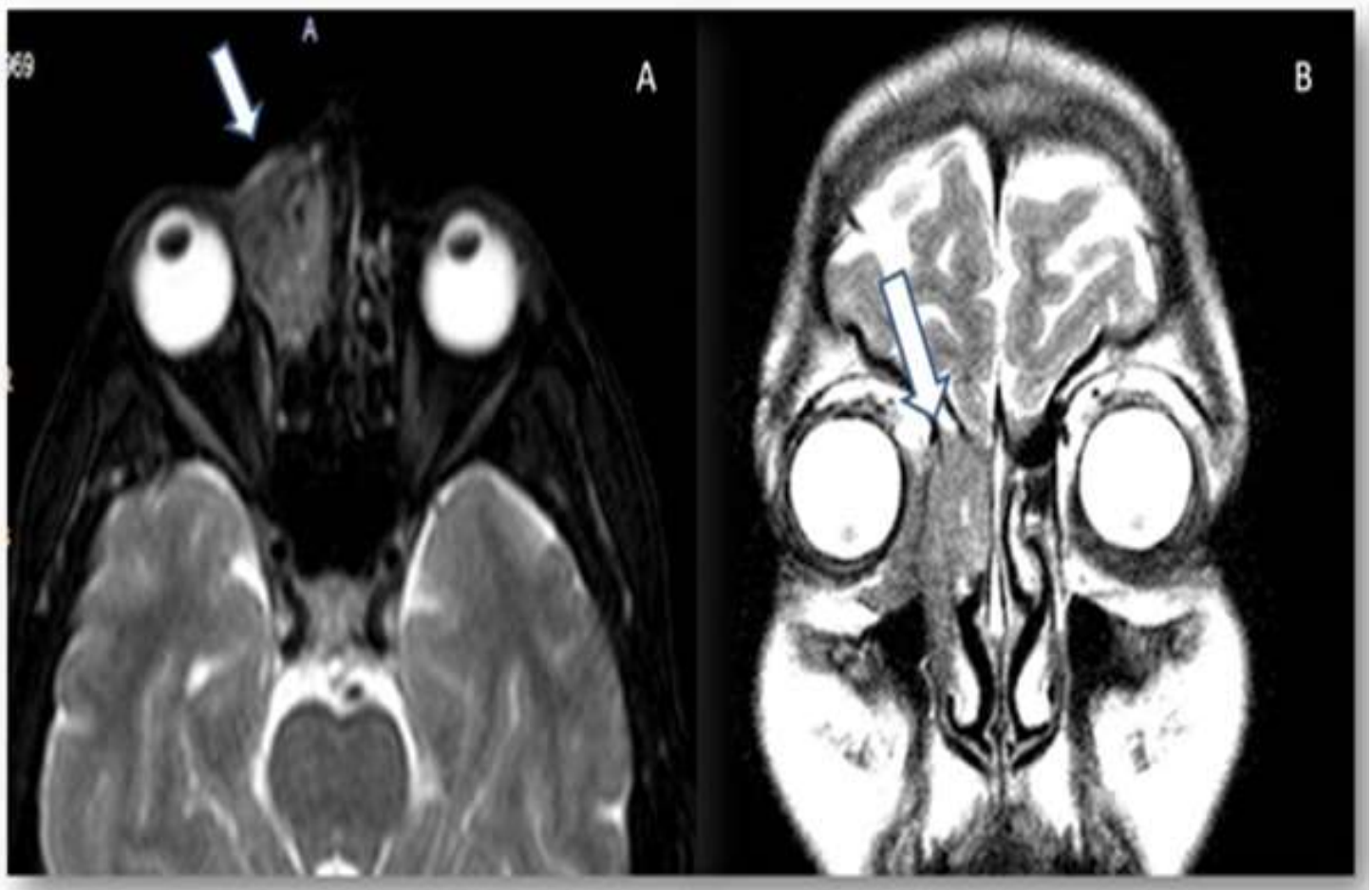

Picture 2: Magnetic resonance imaging (coronal and axial) revealed a 30 X $35 \mathrm{~mm}$ solid mass involving the right lacrimal sac region.

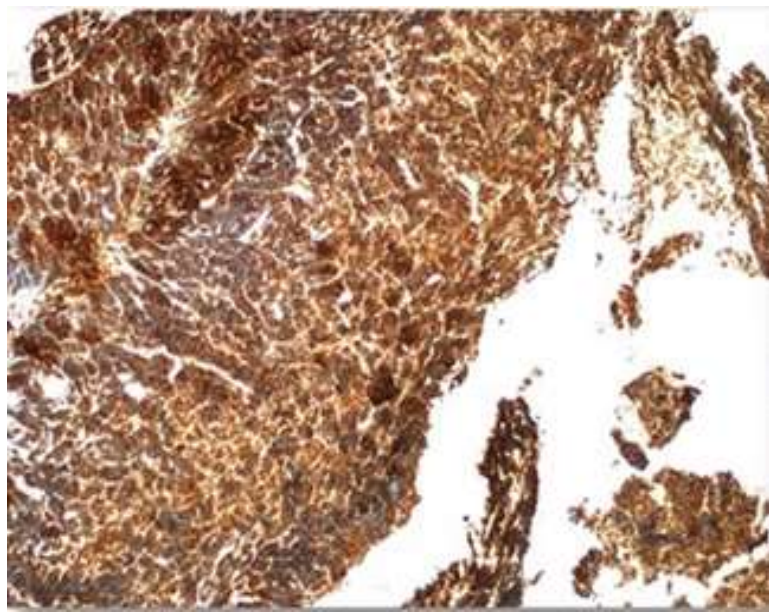

Picture 3A Hematoxylin-eosin staining, monotonous, round-to-oval nuclei, indistinguishable from the cytoplasm tumor cells (second) (H\&E, X400)

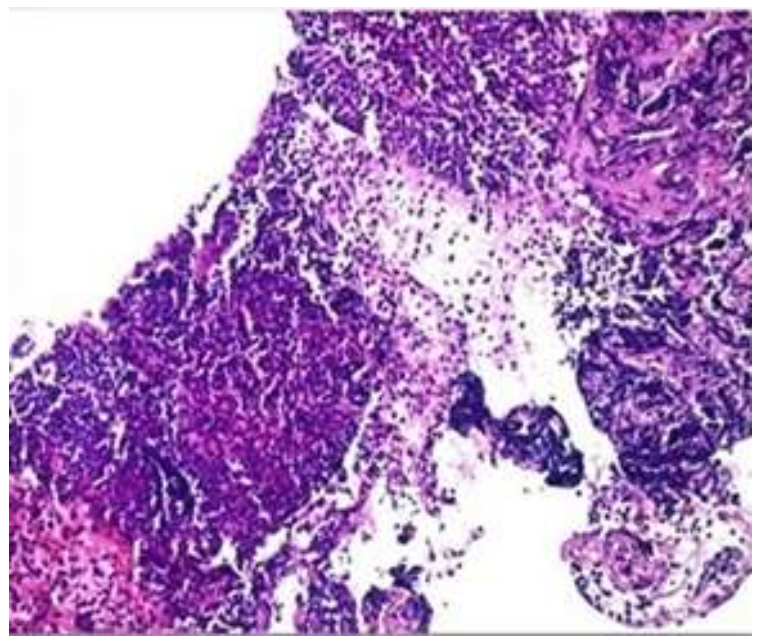

Picture 3B Diffuse membranous staining lymphocytes with CD20, X100 (CD20;Immunohistochemistry for the B-cell Marker.) 
Immunohistochemically, tumor cells were negative for TTF1, NSE, synaptophysin, chromogranin and positive for leukocyte common antigen. The lymphoid cells were strongly and diffuse positive for CD79a, CD20, bcl-2 and negative for CD3, CD45Ro (Figure 3B). Histopathologic and immunohistochemical findings revealed a small $B$ cell non-Hodgkin lymphoma.

Afterwards, whole body scans were performed and the patient was found free of any metastasis. The patient was treated with CHOP regimen chemotherapy (CT) for 8 cycles. Two months after the end of chemotherapy, only moderate epiphora was observed during physical examinations.

\section{Discussion}

Lymphoma arising in the lacrimal sac is extremely rare. In literature, nearly 50 cases of primary lacrimal sac lymphoma have been described over a period of 30 years. Primary neoplasms originating from lacrimal sac are epithelial (75\%) or non-epithelial (25\%) tumors, such as mesenchymal tumors (12\%), melanoma (5\%), and malignant lymphomas (6\%).[14] Carlin and Henderson[1] reported the median age at onset to be 51 years for lacrimal sac lymphoma. Primary nasolacrimal duct lymphoma is more common in females[3,4]. Predominant symptoms of lacrimal sac lymphoma are epiphora and swelling like acute attack of chronic dacryocystitis[1-3]. Blood in the tears has been reported only once. Our case was a forty-four year old female patient with complaints of epiphora on the Eye Study (6). However, a insignificant increased risk of cortical cataract (5) and posterior subcapsular cataract (6) were also reported in these studies respectively in a similar way to our results. Our study differs from these trials with our cataract assessment technique and in our opinion this is one of the strengths of our study. Having not been using data from medical records, we may have reduced the risk of " misclassification bias". Sure, encountering with some artefacts in the LD analysis process is possible but we have tried to avoid from these artefacts by using a standardization method in the measurement procedure.

Nonetheless, some factors such as back scattering of light from the anterior lens area, shadows and light attrition may decrease the amount of light transmitted to the posterior pole of the lens and this may have caused nuclear and posterior area to appear less dense (26). Another limitation of the current study is that it is a not prospective cohort study. We have performed two-way ANOVA, ANCOVA and multiple regression analysis in order to evaluate the effect of gender and age on LD. Although statin use was still found to be more effective on LD than age and gender, our results may have been influenced by some other unpredictable factors.

\begin{tabular}{|c|c|c|c|c|c|c|}
\hline Publication & Age & Sex & Symptoms & $\begin{array}{l}\text { Pathological } \\
\text { Diagnosis }\end{array}$ & Treatment & $\begin{array}{l}\text { Follow-up } \\
\text { /Months }\end{array}$ \\
\hline Palamar M. [9] & 55 & $\mathrm{~F}$ & Epiphora & DLBCL & $\mathrm{CHOP}$ & Alive/25 \\
\hline Kajita F [10] & 77 & M & epiphora and swelling & DLBCL & $\begin{array}{l}\text { RT ( } 30.6 \text { Gy total } \\
\text { dose) }\end{array}$ & Alive/12 \\
\hline Chai CK [11] & 72 & $\mathrm{~F}$ & epiphora and swelling & DLBCL & $\begin{array}{l}\text { Surgery fisrt After } \\
\text { recurrence CHOP }\end{array}$ & Alive/12 \\
\hline $\begin{array}{l}\text { Maharajah KR } \\
{[12]}\end{array}$ & 60 & $\mathrm{~F}$ & epiphora and swelling & $\begin{array}{l}\text { Small-B-cell } \\
\text { lymphoma }\end{array}$ & $\begin{array}{l}\text { Fudorubin } \\
\text { cyclophosphamide }\end{array}$ & $\begin{array}{l}\text { Ex } \\
\text { (pulmonary } \\
\text { embolism) }\end{array}$ \\
\hline Gao HW [13] & 41 & $\mathrm{~F}$ & epiphora and swelling & DLBCL & $\mathrm{CHOP}$ & Alive/14 \\
\hline de Palma P [14] & 72 & $\mathrm{~F}$ & epiphora and swelling & DLBCL & $\begin{array}{l}\text { CHOP first. After } \\
\text { skin recurrence } \\
\text { CHOP and VEP }\end{array}$ & $\begin{array}{l}\text { Ex } \\
\text { (heart failure) }\end{array}$ \\
\hline $\begin{array}{l}\text { Ustaalioglu BB } \\
{[15]}\end{array}$ & 65 & M & epiphora and swelling & $\begin{array}{l}\text { Small } \\
\text { Lymphocytic } \\
\text { lymphoma }\end{array}$ & Surgery & Alive/8 \\
\hline $\begin{array}{l}\text { Schefler AC. } \\
{[17]}\end{array}$ & 10 & M & epiphora and swelling & $\begin{array}{l}\text { MALT } \\
\text { lymphoma }\end{array}$ & $\begin{array}{l}\text { Excisional surgery } \\
\text { first, than } \\
\text { chemotheraphy }\end{array}$ & Alive/30 \\
\hline $\begin{array}{l}\text { Köksal Y. } \\
{[16]}\end{array}$ & 9 & $\mathrm{~F}$ & Swelling & DLBCL & $\begin{array}{l}\text { Excisional surgery } \\
\text { first, than } \\
\text { chemotheraphy }\end{array}$ & Alive/12 \\
\hline Our case & 44 & $\mathrm{~F}$ & epiphora and swelling & $\begin{array}{l}\text { Small B-cell } \\
\text { lymphoma }\end{array}$ & $\mathrm{CHOP}$ & Alive/24 \\
\hline
\end{tabular}


We have excluded the patients with any refractive errors within \pm 3 diopters spherical equivalent and any systemic diseases such as diabetes mellitus, hypertension and connective-tissue diseases. Nevertheless, we know that anti-hyperlipidemic treatment is used for cardiovascular disorders and the patients usually have comorbidities. Surely, some factors like these may have affected our resultsright eye for eight years and a growing mass in the right periorbital region for six months, and pathological diagnosis of the tumor was lymphoma. This case is consistent with literature as the age and complaints of the patient, and also pathological diagnosis being more frequently seen in female patients.

Primary lymphoma of the lacrimal sac is usually Bcell origin. Majority of B cell lymphomas are diffuse large $\mathrm{B}$ cell lymphomas (DLBCL) that runs an

aggressive course but potentially curable [6]. The other common group is mucosa associated lymphoid tissue (MALT) type lymphomas. Only 1 case of natural killer $\mathrm{T}$ - cell lymphoma (NK/T-cell type) was presented before. Its prognosis is worse than the others [7]. Our case was small B cell lymphoma but biopsy specimen size was not enough for subtyping.

The treatment modalities consist of surgery, radiotherapy (RT), CT or a combination of both. RT and/or CT are considered as the primary and definitive treatment [3-5]. Extensive surgery is avoided for functional and cosmetic preservation of the eye $[6,7]$.

In order to obtain a biopsy we used transnasal endoscopic approach to prevent skin spread of the tumor and cosmetic deformity. After the histopathological diagnosis of NHL, the patient was given a CHOP regimen of 8 cycles similar to current approach.

Most common pathology of previous ten years cases was DLBCL $(60 \%)$. One of them were small B-cell lymphoma like our case and one of them was MALT lymphoma. Chai CK[11] et al. performed surgery and after one year follow up when local recurrence occurred at hard palate level, they gave 6 cycles of CT. Kajita[10] et al. proposed RT and their patients underwent RT with 30.6 Gy in total dose. Cases of Schefler[17] et al. and Koksal[16] et al. were in childhood age. Both authors preferred CT regimens after excisional surgery. Ustaalioglu[15] performed surgery alone as a treatment. The other authors preferred CT, mostly CHOP protocol. Two patients treated with CT protocols died also because of systemic factors. Except these two patients no evidence of recurrent tumors has been seen for any other patients with a mean follow-up of 17 months and these treatments have controlled the disease successfully without medical complications. Generally there was no significant difference in survival rates between RT and CT and five year overall survival rate of patients were $80 \%$ [9-17] (Table 1).
The major adverse factors that affect the prognosis of primary lymphoma of nasolacrimal duct seem to be clinical stage and histological type[6-8]. Our patient was treated with $\mathrm{CT}$ and at 24 months follow-up she was alive and free of the disease. There was only one case of small B-cell lymphoma of nasolacrimal duct was reported before and that case died of other causes (pulmonary thromboembolism). So for this histological subtype there is not enough data on survival in comparison to our case.

\section{Conclusion}

Lymphoma of the lacrimal sac is an extremely rare tumor. Suspicion and immediate biopsy are prerequisites for the early diagnosis of malignancies in this area. Otorhinolaryngologists and ophthalmologists must be aware of lacrimal sac tumors in patients with epiphora and rapid swelling.

Conflict of Interest: The authors declare no potential conflicts of interest with respect to the research, authorship, and/or publication of this article.

Ethical issues: All Authors declare that Originality of research/article etc... and ethical approval of research, and responsibilities of research against local ethics commission are under the Authors responsibilities. The study was completed due to defined rules by the Local Ethics Commission guidelines and audits.

Acknowledgement: Role of Authors: MG: Data collection, Manuscript writing/editing. SU: Manuscript writing/editing. GK: Manuscript writing/editing. TK: Data collection, Data analysis. IC: Data collection, Data analysis, Manuscript Editing

\section{References}

1. Carlin R, Henderson JW. Malignant lymphoma of the nasolacrimal sac. Am J Ophthalmol. 1974;78:511-3.

2. Malinvaud D, Badoual C, Rubio MT, Halimi P, Bonfils P. Extraosseous plasmacytoma of the lacrimal duct. B-ENT. 2012;8:285-8.

3. Parmar DN, Rose GE. Management of lacrimal sac tumours. Eye 2003; 17:599- 606.

4. L D Sjö, E Ralfkiaer, B R Juhl, J U Prause, T Kivelä, C Auw-Haedrich, et al. Primary lymphoma of the lacrimal sac: an EORTC ophthalmic oncology task force study. Br J Ophthalmol. 2006; 90:1004-9.

5. Erickson BA, Massaro BM, Mark LP, Harris GJ. Lacrimal collecting system lymphomas: integration of magnetic resonance imaging and therapeutic irradiation. Int J Radiat Oncol Biol Phys. 1994; 29:1095-1103.

6. Gatter KC, Warnke RA. Intravascular large B-cell lymphoma. In: Jaffe ES, Harris NL, Stein H, et al, eds. Pathology and Genetics of Tumours of Hematopoietic and Lymphoid Tissues. Lyon, France: IARC Press: 2001; 177178. World Health Organization Classification of Tumours. 
7. Isaacson PG, Berger F, Muller-Hermeling HK, et al. Extra nodal marginal zone B-cell lymphoma of mucosaassociated lymphoid tissue (MALT lymphoma). In: Jaffe ES, Harris NL, Stein H, et al. World Health Organization classification of tumours. Pathology and genetics of tumours of haematopoietic and lymphoid tissues. Lyons: IARC Press. 2001:157-60.

8. Miller TP, Dahlberg S, Cassady JR, et al. Chemotherapy alone compared with chemotherapy plus radiotherapy for localized intermediate- and high-grade non-Hodgkin's lymphoma. N Engl J Med. 1998; 339:21-26.

9. Palamar M, Midilli R, Ozsan N, Egrilmez S, Sahin F, Yagci A. Primary diffuse large B-cell lymphoma of the lacrimal sac simulating chronic dacryocystitis. Auris Nasus Larynx. 2011; 38:643-5.

10. Kajita F, Oshitari T, Yotsukura J, Asanagi K, Baba T, Kishimoto $\mathrm{T}$, et al. Case of primary diffuse large B-cell lymphoma of lacrimal sac in a Japanese patient. Clin Ophthalmol. 2010; 23:1351-4.

11. Chai CK, Tang IP, Tan TY. Primary lacrimal sac lymphoma with recurrence: a case report. Med J Malaysia. $2013 ; 68: 269-70$
12. Maharajah KR, Hussein A, Mohamad H, Khan SA, At LS. Primarynon-Hodgkins lymphoma of the lacrimal sac: mortality-related epiphora. Orbit. 2009; 28:306-8.

13. Gao HW, Lee HS, Lin YS, Sheu LF. Primary lymphoma of nasolacrimal drain age system: a case report and literature review. Am J Otolaryngol. 2005; 26:356-9.

14. de Palma P, Ravalli L, Modestino R, Grisanti F, Casillo F, Marzola A. Primary lacrimal sac B-cell immunoblastic lymphoma simulating an acute dacryocystitis. Orbit. 2003; 22:171-5.

15. Ustaalioglu BB, Bilici A, Seker M, Gumus M, Ozdemir N, Salman T, et al. Bilateral primary small lympho cytic lymphoma of the lacrimal sac and review of the literature. Leuk Res. 2009; 33:e184-5.

16. Köksal Y, Kiratli H, Varan A, Akçören Z, Büyükpamukçu M. Primary lacrimal sac non-Hodgkin's lymphoma in a child. Int J Pediatr Otorhinolaryngol. 2005; 69:1551-3

17. Schefler AC, Shields CL, Shields JA, Demirci H, Maus M, Eagle RC Jr. Lacrimal sac lymphoma in a child. Arch Ophthalmol. 2003;121:1330-3

Copyright (C) 2016 The Author(s); This is an open-access article distributed under the terms of the Creative Commons Attribution License (http://creativecommons.org/licenses/by/4.0), which permits unrestricted use, distribution, and reproduction in any medium, provided the original work is properly cited. All Rights reserved by international journal of Medical Science and Discovery. 